\title{
ICT Skills Application in Teaching and Research by Lecturers in some Selected Universities in Nigeria
}

\author{
Shiekuma Felix Tor ${ }^{1}$, Apagu Liviticus $(C L N)^{2}$ \\ \& Segun Joshua Oluwafemi $(C L N)^{1}$
}

\author{
${ }^{1}$ Department of Library and Information Science, Ahmadu Bello University, Zaria, Nigeria \\ talk2felixo@gmail.com \\ ${ }^{2}$ Department of Library and Information Science, Federal University of Lafia, Nasarawa State, \\ apagulevi@gmail.com \\ ${ }^{1}$ Department of Library and Information Science, Ahmadu Bello University, Zaria, Nigeria \\ oluwafemisj@gmail.com
}

Received: 26 $^{\text {th }}$ Feb. 2020 Accepted: $18^{\text {th }}$ May 2020 Date of Publication: June 2020

\begin{abstract}
This research was carried out to investigate ICT skills application in teaching and research by lecturers in some selected universities in Nigeria. The cross-sectional survey research design was adopted. The targeted population were lecturers in the three universities in Benue State; namely, University of Agriculture, Makurdi; Benue State University, Makurdi and the University of Mkar, with a total of 1,537 lecturers. Out of this population, 306 lecturers were drawn as a sample for the study. Cluster and simple random sampling were employed for sample selection. Questionnaire was used as the instrument for data collection. The data collected from the respondents were sorted, organized, presented and analysed using mean and standard deviation, while inferential statistics in form of One-way Analysis of Variance (ANOVA) was used for testing the two null hypotheses at 0.05 level of significance. The study revealed that university lecturers in Benue State apply ICT skills in teaching to some extent, and in the area of research, they apply their ICT skills to a moderate extent. The result of two hypotheses showed that there is a difference in the extent of ICT skills application in teaching by the lecturers in the Federal, State and Private Universities, while, for ICT skills application in research by the lecturers there is no significant difference in the extent of the application in the Federal, State and Private Universities in Benue State. It was therefore recommended that ICT inclined professional librarians and university ICT personnel should offer more personalized support services to lecturers that need the training to be able to integrate ICTs in teaching and research processes. The management of the
\end{abstract}


universities should furnish lecturers' offices and classrooms with ICT tools and Internet connectivity as this would grant lecturers enabling environment to apply their ICT skills in research and teaching sessions.

Keywords: ICT Skills, Lecturers, Nigeria, Research, Teaching, Universities

\section{Introduction}

Throughout the world, universities are not just acknowledged as the pinnacle of higher education but as the nation's depositories of human knowledge. The knowledge and ideas gained in universities are important ingredients for the scientific, technological, economic and social advancement of any nation. The Federal Government of Nigeria has corroborated this by clearly stating in her National Policy on Education (NPE, 2004), that university education is missioned to make an optimum contribution to national development by way of high-level manpower training, and to promote and encourage scholarship. This implies that Nigerian universities are both the providers of knowledge and professionals to be moved to society which serves as added competitive advantages of the country. To fulfil this lofty goal, university lecturers become major stakeholders in equipping people with the knowledge and skills required in undertaking tasks that can increase the developmental status of the nation. Teaching and research are means through which lecturers actualize the aforestated.

The primary roles of university lecturers are teaching and research. Research is a methodical inquiry with the view of increasing the body of knowledge. Okpe, Simisaye, and Otuza (2013) alluded to research as the cradle of knowledge generation, denoting the crucial position of research in stimulating the fortunes of a nation and ensuring the well-being of the citizenry in this knowledge-based era. This rationalises why lecturers are expected to engage in the generation of new knowledge and promptly disseminate their research results to both government and industries. By doing so, Chukwuedo and Igbinedion (2014) noted that university research can serve as a strong source through which government and industries can accelerate the nation's development. Research is also one of the means through which lecturers grow professionally by staying current in their scholarship and contribute significantly to national development through community services. In recognition of this, Egbri (2015) noted that researches are conducted to discover, reinforce or refine knowledge and ultimately develop new knowledge that can become the basis for development. This implies that university research outputs are powerful tools for accessing and advancing knowledge and generating life-transforming ideas. But apart from this, university lecturers are also central in training minds through teaching.

According to Kpolovie and Onoshagbegbe (2017), teaching responsibilities of lecturers encompasses traditional pedagogy and supervision of students' research works, distance and technology-based learning/instructions in addition to organizing and directing of group/collaborative learning and general students mentoring/advising. The scope of teaching is beyond the four

\section{URL: http://journals.covenantuniversity.edu.ng/index.php/cjlis/}


walls of a classroom. It assumes the dimensions of providing learners with the necessary skills under or outside the canopy of the classroom to enable them to become agents of change in society. In support, Ezeugwu, et al., (2016) concurred that teaching should endow learners with experiences such as knowledge, understanding, skills, capacity ability, talents, information, and details required for use in the future through guidance and direction. Given this, university lecturers occupy a tremendous position in guiding students to secure the qualitative and quantitative amount of experience that will stimulate the maximal development of their inbuilt potentials. Moreover, teaching is the essential means through which the potentials needed for the nation's greatness, glory and wealth are discovered, explored and channelled correctly without incurring wastages. With this, the importance of university lecturers is underscored, seeing that their roles determine whether the future of a nation will be bright or bleak.

Decades ago, teaching and research have experienced a paradigm shift from the traditional method that is anchored on chalk and talk, pen and paper, towards a new style of teaching and conducting researches occasioned by Information and Communication Technology (ICT). To uphold this, Alandejani and Almadani (2018) admitted that ICT has become a foundation for innovation and enhancement of efficiency for many professional practises and roles across the globe. Relating to professional roles of lecturers, particularly, the application of ICT tools has massively revitalized and reinforced lecturers' statutory roles through the effective delivery of education curriculum by creating multiple channels of interaction and enhancing research productivity. As a result, ICT turned out to be a dire necessity for lecturers to survive in this era when traditional pen, chalkboard and paper are gradually becoming forgotten subjects. This implies that ICT is now a superior option in handling all the academic activities lecturers embark on.

ICT is a generic term that combines computer and communication technologies used in information handling. Jagadesh (2017) defined ICT as "a diverse set of technological tools and resources used to communicate, and to create, disseminate, store, and manage information". It covers products that will be able to store, manipulate, retrieve, transmit and at the same time receive information (text, sound, motion, etc.) transmitted electronically in digital form. Some of these products include computer hardware and software, the network (Internet, intranets, and extranets), World Wide Web (WWW) and other digital devices like audio, video, camera and so on. Nwizeg, Chukwunons, Kpabeb and Mmeah (2011) stated that "ICT tools can be used to find, explore, analyse, exchange and present information responsibly from unlimited sources and without discrimination". These potentials of ICT have made it very instrumental in driving lecturers toward the actualisation of their teaching and research functions.

Undoubtedly, ICTs have significantly impacted on the quality and quantity of teaching and research.

\section{URL: http://journals.covenantuniversity.edu.ng/index.php/cjlis/}


The advent of ICT has increased research productivity by providing academics in different locations with the platform to collaborate for research projects because of the borderless and distance-less nature of the Internet. The knowledge produced by such collaborations is published online for global consumption without the limitation of geographical space. ICT products such as productivity tools, Statistical Package for Social Sciences (SPSS), referencing software and antiplagiarism software enhance research management from the conception of a research problem to data analysis and result transmission. E-learning tools such as wikis, podcasts, blogs, e-groups, webcasts, and other platforms are available to enable teaching within and outside the classroom environment. These developments seemed to have bulldozed the walls of lecture halls because both teaching and learning can occur anywhere at any time and with anybody. However, lecturers must possess the required ICT skills before they can successfully integrate ICTs in conducting research and imparting knowledge. To buttress this, Chukwuedo and Igbinedion (2014) pointed out the need for lecturers to be equipped with the relevant technologies to withstand the adoption, application, and use of ICT applications to discharge their duties effectively.

Possessing ICT skills is not just necessary for lecturers but very sacrosanct. It is so because the era of lecturers surviving and proving to be relevant in their academics without ICT skills is gone. These skills are increasingly becoming a prerequisite for every effective and efficient professional practice. Buabeng-Andoh (2012) defined ICT skills "as being able to handle a wide range of varying computer applications for various purposes". ICT skills refer to lecturers' ability to know ICT tools, effectively manage and operate them in the course of teaching and conducting researches. Mbengo (2014) noted that the use of ICTs by lecturers improves the process of obtaining and disseminating new information to students from multimedia technologies and the Internet. He further stated that ICT use brings greater access to knowledge, improve the archival capability of knowledge and ensure teaching effectiveness. This implies that commendable teaching and research outputs are a consequence of ICT use in lesson delivery and research management. It is therefore not difficult to explain the affection and patronage that ICT has attracted from university lecturers.

In Nigeria, there are positive advancements with regards to using ICT to improve the professional activities of lecturers (Anne, Imam \& Odumuh, 2014). Lecturers' application of ICT skills in their core duties have conferred on them contemporary teaching and research experiences. With the aid of ICT applications, university lecturers in some Nigerian universities are now holding online lectures with their outlying students. Without any empirical work, we counted on personal contacts to mention Bingham University, National Open University, and Covenant University as examples of the universities where lectures are partially or fully delivered online. Even 
in physical classroom settings, the use of ICT tools like computers, amplifiers, smartboards etc., have made teaching more convenient for lecturers and interesting to students. To discuss further, the inherent potentials of ICT such as high-performance speed, large storage capacity and accuracy is advantageous to lecturers in course writing, processing of students records and storing teaching materials. Apart from this, the opportunities provided by social network outfits have been leveraged by lecturers to deliver online instructions to students. This is progressively securing victory over the age-long barriers of time, space and place as Internet technology present innovative alternatives to traditional classrooms with its attendant inadequacies. As a result, the Internet has become a platform for lecturers in Nigerian universities to learn from contemporaries around the world and search for the latest information to enrich curriculum contents. All of these stresses the indispensability of ICT application in supporting effective teaching.

In his study, Akpan (2008) disclosed that ICT use is strategic in improving the quality of researches and publications in Nigerian universities through the use of quality literature materials from the Internet. The use of ICT applications by lecturers assisted in smoothening their research experiences throughout the whole gamut of the research process. Educational investigation chores such as literature review, paper writing, spelling or grammar check, referencing, statistical analysis, and sending off manuscripts to publishers are now facilitated by technology. This has helped in relieving lecturers from huge financial burden and time previously expended on conducting inquiries. More than this, technology has provided a platform for lecturers from different universities of the nation to collaborate on research projects, thereby enriching the intellectual content of research works as a result of inputs from diverse scholars. Knowledge gained from such investigations is now published online for global visibility and consumption. Despite these laudable benefits, there is still limited shreds of empirical evidence on how lecturers are applying their ICT skills in teaching and research in some Nigerian universities. This raised a concern that birthed this investigation.

\section{Statement of the Problem}

Globally, universities are the pinnacle of higher education acknowledged as reservoirs of human knowledge which is depended upon in this knowledge-based economy. This connotes that the ideas and knowledge gained in universities are critical for advancement across nations of the world. Considering the placement of universities, the Federal Government of Nigeria through National Policy on Education (2004) mandated university education to make an optimum contribution to national development by way of high-level manpower training and to promote and encourage scholarship. Because of this, the statutory duties of university lecturers in training minds and generating knowledge through research become central in fulfilling the above lofty goals. Interestingly, the influx of ICT and its attendant benefits have

\section{URL: http://journals.covenantuniversity.edu.ng/index.php/cjlis/}


induced a transition from the traditional method of teaching that is anchored on chalk and talk, pen and paper, towards the technology-driven style of teaching and conducting researches. ICT usage enables lecturers to manage complex academic records, communicate easily, plan and deliver lectures through multiple channels, access limitless sources of information and perform allied activities effectively. Despite these laudable benefits, there are still limited shreds of empirical evidence on how lecturers in the universities in Benue State are applying their ICT skills in teaching and research, even though Ridwan, Tor and Mohammed (2019) found the level of their ICT skills to be high. Considering the efficiency and effectiveness ICT usage releases to core duties of lecturers and the possible pitfalls that may result if lecturers miss out in applying their skills to use technology in their academic activities, it is empirically relevant to investigate ICT skills application in teaching and research by university lecturers in the context of Benue State.

\section{Purpose of the Study}

The purpose of the study is to:

1. Determine the extent to which lecturers in the Universities in Benue State apply ICT skills in teaching.

2. Ascertain the extent to which lecturers in the Universities in Benue State apply ICT skills in research.

\section{Research Hypotheses}

The following null hypotheses were formulated for the study:
$\mathrm{Ho}_{1}$ There is no significant difference in the extent of ICT skills application in teaching by the lecturers in the federal, state and private Universities in Benue State.

$\mathrm{Ho}_{2}$ There is no significant difference in the extent of ICT skills application in research by the lecturers in the federal, state and private Universities in Benue State.

\section{Literature Review}

Excellent teaching and learning outcomes are dependent on the extent to which lecturers can integrate ICTs in the whole process. To substantiate this, Akpan (2014) disclosed that lecturers with good ICT proficiency were discovered to be more successful in classroom instruction, record-keeping, and communication. In their study on ICT competence of lecturers, Archibong, Anijaobi-Idem and Ogbiji (2010) found that utilizing ICT in the context of teaching and learning by the sampled lecturers was seriously restricted. This was because the responses of the majority of the sampled lecturers as regards the use of ICT in all the indices considered was below $50 \%$. In a similar study on ICT use, Gombe et al., (2016) found that lecturers from North-western Nigeria were unable to effectively and efficiently maximize ICT in the teaching-learning process. However, Ahmed (2013) disclosed that most of the studied lecturers were computer/Internet proficient to arrecs teaching materials online. The 55 of the above studies are $n \ldots \ldots$ cheering especially in this era of globalization when lecturers need ICT expertise to compete for standard in

URL: http://journals.covenantuniversity.edu.ng/index.php/cjlis/ 
teaching with their contemporaries around the world. Based on this, this study became more relevant to further investigate the current situation of universities in Benue State on the subject matter, following the new windows of opportunity being created by technology which can be seized to improve teaching.

Regarding the application of ICT skills in research, Ekpoh and Etor (2012) reported that the ICT competency level of lecturers for creating knowledge was low. Inversely, Akpan (2014) found that ICT competence enhanced job efficacy of lecturers concerning research/publication. In the same way, Ojeniyi and Adetimirin (2016) discovered that lecturers majorly possessed ICT skills in form of general computer operations, Internet browsing and Internet searching; and these skills influence their use of e-resources to support research endeavours. The outcome of this is increased research publication; enhanced quality of discussions at academic conferences; and improved participation in community service (Iroaganachi \& Izuagbe, 2018). In another study, Abba and Adamu (2019) found that a high percentage of university lecturers considered were averagely proficient in using Internet services and resources for academic activities. In support of this, Amua-Sekyi and Asare (2016) reported that ICT skills of lecturers are good and are particularly used in sending e-mails, accessing the Internet, preparing PowerPoint presentation, downloading documents and searching databases. Each of the aforestated aspects greatly influences lecturers to be productive in their academic researches. By implication, ICT skills application to research is a dire necessity for university lecturers who desire to remain professionally relevant in this current age of knowledge-based economy. This further strengthened the objectives of this current research.

\section{Methodology \\ Research Design}

The cross-sectional survey research design was used for the study. According to Kothari (2011) crosssectional survey design involves data collection from a population, or a representative subset, at one specific point in time. The decision of this research design was informed by the fact that the data on lecturers' ICT skills application in teaching and research was collected at one point in time but from different universities (groups) under consideration.

\section{Population of the study}

The population for this study constituted all the lecturers from the three full-time accredited universities in Benue State, amounting to 1,537 lecturers: $\mathrm{UMM}=144 ; \quad \mathrm{BSUM}=604 ; \quad$ and $\mathrm{UAM}=789$. The three universities included: University of Mkar, Mkar (UMM); Benue State University, Makurdi (BSUM); and University of Agriculture, Makurdi (UAM). The wisdom for choosing these institutions was based on the limitedness of shreds of empirical evidence on ICT skills application to teaching and research by lecturers in the universities in Benue State, and the need for improved 
teaching that keeps intensifying within the state.

\section{Sample and sampling technique}

In determining the sample size for the study, Krejcie and Morgan (1970) table was used, and the sample size for a population 1,537 is 306 . Based on this, the sample size for the study became 306 lecturers; 29 lecturers at UMM; 120 lecturers at BSUM and 157 lecturers at UAM. The three universities were clustered into federal, state and private universities while simple sampling technique was used for sample selection. This was to afford every potential respondent opportunity to be part of the sample for the study.

\section{Instrument for Data Collection}

A self-structured questionnaire based on insights from reviewed pieces of literature was used as the instrument for data collection. The questionnaire consisted of two segments; the first segment involved a question on ICT skills application in teaching with prewritten responses for ticking. The second part cantered on questionnaire items on ICT skills application in research. A four-point modified Likert scale of high extent, moderate extent, some extent and low extent was used in measuring the level of lecturers' ICT skills application in teaching and research.

\section{Validity and Reliability}

Three lecturers from the fields of librarianship and computer science scrutinized the instruments, and the observations raised were duly followed, thus reinforcing the quality of the instrument. After this, a pilot study was carried out on ten (10) lecturers from Ahmadu Bello University, Zaria, and the result of the pilot study was tested using Cronbach alpha reliability test, and a reliability level of 0.98 was obtained, which confirmed the reliability of the instrument.

\section{Data collection and Analysis}

A total of 306 copies of questionnaires were distributed to lecturers in the studied universities with the help of clerical staff from the offices of the Heads of departments within one month and a week. Out of the copies of questionnaires distributed, a total of two hundred and seventy-three (273) copies were retrieved and used for the study. The data generated were analysed using descriptive statistics in the form of mean and standard deviation, with the aid of the Statistical Package for Social Science (SPSS). While inferential statistic in the form of One-Way Analysis of Variance (ANOVA) was used to test the two hypotheses. This was justified by the fact that the hypothesis involved testing the mean of three independents groups. For the sake of making a decision, the constant mean of 2.5 was used to ascertain the level of agreement or disagreement of lecturers to the questionnaire items on their extent of ICT skills application to teaching and research activities. A mean score of 3.41-4.20 indicated high extent; 2.613.40 indicated a moderate extent; 1.81 2.60 indicated some extent; while 1.001.80 indicated a low extent. 


\section{Result}

Table 1: The Extent of Applying ICT skills To Teaching by Lecturers $\mathrm{N}=135,110,28$

\begin{tabular}{|c|c|c|c|c|c|}
\hline $\mathrm{S} / \mathrm{N}$ & Skills & Univ. & Mean & SD & Remark \\
\hline \multirow{3}{*}{1} & \multirow{3}{*}{ Web Content Creation } & UAM & 2.35 & 1.16 & Some extent \\
\hline & & BSUM & 2.14 & 0.82 & Some extent \\
\hline & & UMM & 1.92 & 0.94 & Some extent \\
\hline \multirow{3}{*}{2} & \multirow{3}{*}{ PowerPoint Presentation } & UAM & 3.33 & 0.92 & Moderate extent \\
\hline & & BSUM & 3.10 & 0.91 & Moderate extent \\
\hline & & UMM & 2.60 & 1.03 & Some extent \\
\hline \multirow{3}{*}{3} & & UAM & 2.44 & 1.11 & Some extent \\
\hline & Network Classroom & BSUM & 2.27 & 0.89 & Some extent \\
\hline & Gadgets & UMM & 2.46 & 0.92 & Some extent \\
\hline \multirow{3}{*}{4} & \multirow{3}{*}{ Create Word Documents } & UAM & 3.53 & 0.86 & High extent \\
\hline & & BSUM & 3.29 & 0.87 & Moderate extent \\
\hline & & UMM & 3.25 & 0.89 & Moderate extent \\
\hline \multirow{4}{*}{5} & \multirow{3}{*}{ Perform Technical Tasks } & UAM & 2.11 & 1.16 & Some extent \\
\hline & & BSUM & 1.72 & 0.78 & Low extent \\
\hline & & UMM & 2.07 & 0.89 & Some extent \\
\hline & Grand Mean & & 2.57 & & Some Extent \\
\hline
\end{tabular}

Table 1 shows the extent to which lecturers in the universities in Benue State apply ICT skills to teaching. Using the grand mean of 2.57. It can be said that the extent to which lecturers apply ICT skills to teaching is low.

Table 2: The Extent of Applying I ICT skills To Research by Lecturers N=135, 110, 28

\begin{tabular}{clcccc}
\hline S/N & Skills & Univ. & Mean & SD & Remark \\
\hline \multirow{2}{*}{1} & \multirow{2}{*}{ Database Searching } & UAM & 2.91 & 1.08 & Moderate extent \\
& & BSUM & 3.01 & 0.94 & Moderate extent \\
& & UMM & 2.91 & 1.08 & Moderate extent \\
\multirow{2}{*}{2} & \multirow{2}{*}{ Internet Navigation } & UAM & 3.26 & 1.07 & Moderate extent \\
& & BSUM & 3.14 & 1.00 & Moderate extent \\
& & UMM & 2.75 & 1.14 & Moderate extent \\
\multirow{2}{*}{3} & Present Data on & UAM & 2.86 & 1.05 & Moderate extent \\
& Spreadsheet & BSUM & 2.76 & 0.96 & Moderate extent \\
& & UMM & 2.36 & 1.06 & Some extent \\
4 & Develop Programs & UAM & 2.04 & 1.01 & Some extent \\
& & BSUM & 1.92 & 0.85 & Some extent \\
& & UMM & 2.10 & 0.97 & Some extent \\
\multirow{2}{*}{5} & Create Word Documents & UAM & 3.53 & 0.86 & High extent \\
& & BSUM & 3.29 & 0.87 & Moderate extent \\
& & UMM & 3.25 & 0.89 & Moderate extent \\
\hline \multirow{2}{*}{ Grand Mean } & & 2.76 & & Moderate extent \\
\hline
\end{tabular}


Table 2 shows the extent to which lecturers in the universities in Benue State apply ICT skills to research. With the grand mean of 2.76 , it can be held that the extent to which lecturers apply ICT skills to research is moderate.

\section{Hypotheses Testing}

Ho⿱ There is no significant difference in the extent of ICT skills application in teaching by the lecturers in the Federal, State and Private Universities in Benue State.

Table 3: One-Way ANOVA Result on Difference in the Extent of ICT Skills Application in Teaching by the Lecturers in the Federal, State and Private Universities in Benue State.

\begin{tabular}{lccccc} 
& Sum of Squares & Df & $\begin{array}{c}\text { Mean } \\
\text { Square }\end{array}$ & F & Sig. \\
\hline Between Groups & 148.250 & 2 & 74.125 & 3.844 & \\
Within Groups & 5206.453 & 270 & 19.283 & & .023 \\
& & 272 & & & \\
\hline Total & 5354.703 & 272 & & \\
\hline
\end{tabular}

Significance level $.05^{*}$

Table 3 clearly shows that there is a statistically significant difference in the extent of applying ICT skills to teaching by the lecturers in the Federal, State and Private Universities in Benue state as determined by the one-way ANOVA [F $(2,270)=3.844, p=.023]$. Therefore, the null hypothesis has been rejected. To establish where the difference existed, post hoc multiple comparisons using the Tukey test was carried out. The test revealed that there is no significant difference in the extent of ICT skills application to teaching by the lecturers in the Federal $(\mathrm{p}=.266)$ and Private $(\mathrm{p}$ $=.997)$ Universities in Benue State. Whereas, there is a significant difference in the extent of ICT skills application to teaching by the lecturers in the State $(\mathrm{p}=.024)$ and the other two universities.

$\mathrm{Ho}_{2}$ There is no significant difference in the extent of ICT skills application to research by the lecturers in the Federal, State and Private Universities in Benue State.

Table 4: One-Way ANOVA Result on Difference in the Extent of ICT Skills Application in Research by the Lecturers in the Federal, State and Private Universities in Benue State.

\begin{tabular}{lccccc}
\hline & Sum of Squares & Df & $\begin{array}{c}\text { Mean } \\
\text { Square }\end{array}$ & F & Sig. \\
\hline Between Groups & 88.948 & 2 & 44.474 & 2.119 & \\
Within Groups & 5665.513 & 270 & & & .122 \\
\hline Total & 5754.462 & 272 & & & \\
\hline
\end{tabular}


Table 4 explicitly reveals that there is no statistically significant difference in the extent of applying ICT skills to research by the lecturers in the Federal, State and Private Universities in Benue State as determined by the one-way ANOVA [F $(2,270)=2.119, \mathrm{p}=.122]$. Therefore, the hypothesis has been retained.

\section{Discussion}

Application of ICT skills to professional practices to ensure improved discharge of statutory duties has become an expectation in almost all spheres of human ventures. This formed the reason for this research effort; to ascertain the extent to which lecturers apply ICT skills to teaching in the Universities in Benue State. The result as contained in Table 1 uncovered that the lecturers apply ICT skills to teaching to some extent. This could be attributed to the inability of the universities to adopt adequate devices needed in the teaching process, indicating that the teachinglearning process that is facilitated by technology has not gained warm reception in the universities. The outcome of the study aligns with Archibong et al (2010) who found that utilizing ICT in the context of teaching and learning by the sampled lecturers was seriously restricted. By implication, the lecturers in the universities understudy might not record good teaching results since the teaching process is not enhanced by technology. Furthermore, lecturers may find it challenging to manage students' records due to astronomical growth in the universities' yearly intake.

The extent to which lecturers integrate ICTs in research is greatly dependent on their ICT skills. A look at Table 2 revealed that the lecturers apply ICT skills to research to a moderate or average extent. It is glaring that the lecturers apply their skills to integrate ICT in research endeavours more than their pedagogical functions. This sharp disparity might have been occasioned by the enabling environment created for research through the provision of facilities by their respective institutions, or the lecturers' motivation of applying their skills to produce research works required for promotion. This study is in line with Amua-Sekyi and Asare (2016), who discovered that ICT skills of lecturers are good and are particularly applied to access the Internet, download documents and search databases. Also, the result reveals support for Ojeniyi and Adetimirin (2016), who unearthed that lecturers greatly apply their ICT skills to Internet browsing and Internet searching. By implication, since the application of their ICT skills in research stand at average, this would help them to have access to knowledge that would keep them current in their scholarship and produce intellectually rich researches. However, lecturers must not be contented with the status quo because technology is constantly getting more complex, and to move along with the growing trend requires an incessant upgrade.

The first hypothesis revealed the existence of difference in the extent of ICT skills application to teaching by the lecturers in the State, Federal and Private Universities. The difference found in the study may be so because of ownership factors such as inconsistent support for ICT initiatives and training from the State Government. The difference would reflect on the teaching outcomes of the individual university. The second hypothesis denied the existence of difference in the extent of ICT skills application to research by the lecturers in the Federal, State and Private Universities. This revelation 
points to the fact that irrespective of the type of university, the effectiveness and efficiency associated with ICT has made lecturers to equally rely on it to improve research development in universities.

\section{Conclusion}

Based on the outcome of the study, it was concluded that lecturers in the selected universities in Nigeria apply ICT skills in teaching to some extent. While, in the area of research, the lecturers apply their ICT skills to a moderate extent. This indicates that research outputs and teaching outcomes in the universities cannot be expected to be high except the current situation improves. This, therefore, give room for further studies to be conducted to understand the influence of lecturers' ICT usage on learning outcomes in the universities.

\section{References}

Abba, T \& Adamu, L.A.G. (2019). University Lecturers' Level of Awareness and Proficiency of Internet Services and Resources for Academic Activities in Adamawa State, Nigeria. Library Philosophy and Practice (e-journal). Retrieved from

https://digitalcommons.unl.edu/l ibphilprac/2615

Ahmed, S. M. Z. (2013). Use of electronic resources by the faculty members in diverse public universities in Bangladesh. The Electronic Library, 31(3): 290312.

\section{Recommendations}

Consequential to the findings of the study, it was recommended in this study that:

1. ICT inclined professional librarians and university ICT personnel should offer more personalized support services to lecturers that need the training to proficiently integrate ICTs in teaching and research processes. This would make the training more practical and result in high productivity.

2. The management of the universities should furnish lecturers' offices and classrooms with ICT tools and Internet connectivity. This would grant lecturers enabling environment to apply their ICT skills in research undertakings while in offices and incorporate ICT tools in teaching sessions.

Akpan, C. P. (2008). Lecturers' perception of the Role of ICT in the Management of University Education for Sustainable Development in Nigeria. Nigerian Journal of Educational Administration and Planning. 8 (1), 113-127.

Akpan, C.P. (2014). ICT Competence and Lecturers' Job Efficacy in Universities in Cross River State, Nigeria. International Journal of Humanities and Social Science, 4(10), 259-266. Retrieved from http://www.ijhssnet.com/journals/ Vol_4_No_10_August_2014/31.p df

Amua-Sekyi, E. T., \& Asare, P.Y. (2016). A Survey of Information

URL: http://journals.covenantuniversity.edu.ng/index.php/cjlis/ 
Communication Technology Literacy among Lecturers. Information and Knowledge Management, 6(8).

Anne, J.H. Imam \& Odumuh, T. (2014). Prospects and Challenges of Elearning in Nigerian Universities. International Journal of Technology. 3, 320-327

Archibong, I.A., Ogbiji, J.E. \& Anijaobi-Idem, F. (2010). ICT Competence among Academic Staff in Universities in Cross Rivers State, Nigeria.

Basri, W., Alandejani, J.A., \& Almadani, F.M. (2018). ICT Adoption Impact on Students' Academic Performance: Evidence from Saudi Universities. Education Research International, pp. 1-9. Retrieved from

https://doi.org/10.1155/2018/1240 197

Buabeng-Andoh, C. (2012). Factors Influencing Teachers' Adoption and Integration of Information and Communication Technology into Teaching: A Review of the Literature. International Journal of Education and Development using Information and Communication Technology (IJEDICT), 8(1), 136-155.

Chukwuedo, S.O., \& Igbinedion, V.I. (2014). ICT Competences and Capacity Building Needs of Technical and Vocational Education Lecturers in Nigerian Universities. African Journal of Interdisciplinary Studies, 7, 4553.
Egbri, J. N. (2015). Use of Internet Resources For Research by Postgraduate Business Education Students in Universities in SouthEast and South-South Nigeria (Doctoral Dissertation, University of Nigeria, Nsukka).

Ekpoh, U, \& Etor, C.R. (2012). Academic Staff Utilization of Information and Communication Technology and Knowledge Creation in Cross River State Universities. African Higher Education Review (AHER), 6, 38-51.

Emeasoba, N.C. \& Ezenwafor, J.I. (2014). Assessment of Computer Operation and Networking Competencies Possessed by Office Technology and Management Lecturers in Tertiary Institutions in Anambra and Enugu States, Nigeria. Journal of Emerging Trends in Educational Research and Policy Studies (JETERAPS) 5(7): 1-5

Ezeugwu, J.J.O., Abiogu, G.C., Ibeh, E., Asogwa, U.D., Nwangwu, E., \& Afufu, J.E. (2016). Assessment of Mathematics Lecturers' Competencies in the Application of Information and Communication Technology (ICT) in Mathematics Instruction in Tertiary Institutions. Global Journal of Pure and Applied Mathematics, 12(4), 3701-3726.

Federal Republic of Nigeria NPE (2004). National Policy on Education. Lagos: NERDC

Gombe, S.Y., Jega, K.I., Dahiru, A.S., Aji, A.A., Sani, A., \& Usman, A. (2016). The Use of Information

URL: http://journals.covenantuniversity.edu.ng/index.php/cjlis/ 
and Communication Technology (ICT) by Lecturers in NorthWestern Nigeria. Computer Engineering and Intelligent Systems, 7(8), 1-6.

Iroaganachi, M.A. \& Izuagbe, R. (2018). A Comparative Analysis of the Impact of Electronic Information Resources Use Towards Research Productivity of Academic Staff in

Nigerian Universities. Library Philosophy and Practice (ejournal). Retrieved from https://digitalcommons.unl.edu/li bphilprac/1702

Jagadesh, M. (2017). ICT Tools Usage among Faculty of Education in Teaching Learning. International Journal of Indian Psychology, 4(2), 72-76.

Kothari, C. R. (2011). Research Methodology: Methods and Techniques. New Delhi: New Age International Publishers.

Kpolovie, P. J. \& Onoshagbegbe, E. S. (2017). Research Productivity: HIndex And I10-Index of Academics In Nigerian Universities. International Journal of Quantitative and Qualitative Research Methods, 5(2), 63.

Krejcie, R. V. \& Morgan, D.W. (1970). Determining Sample Size for Research. Educational and Psychological Measurement Vol. 30, pp. 607-610

Mbengo, P. (2014) E-learning Adoption by Lecturers in Zimbabwe selected State Universities: An Application of Technology Acceptance Model. Journal of Business Administration and Education, 6 (1), 15-38.

Nwizeg, K.S., Chukwunons, F., Kpabeb, C. and Mmeah, S. (2011). The Impact of ICT on Computer Application. UKSim 5th European Symposium on Computer Modeling and Simulation.

Ojeniyi, A.O. \& Adetimirin, A.E. (2016). ICT Literacy Skills and Electronic Information Resources by Lecturers in Two Private Universities in Oyo State, Nigeria. Library Philosophy and Practice (e-journal). 1443.

Okpe, I.J, Simisaye, A.O. \& Otuza, C.V. (2013). Research Output and Pattern of Publication among Faculty in Nigerian Private Universities: Babcock University Experience. Information and Knowledge Management, 3(9), 19.Ridwan, S.M., Tor, S.F., \& M.F., Mohammed. (2019). Assessment of ICT Competencies and Use of Electronic Information Resources by Lecturers in Universities in Benue State, Nigeria. International Journal of Information Management Sciences (IJIMS). 1(1), 1-22. Retrieved from http://ijims.org/index.php/IJIMS/a rticle/view/46/18 